Journal of Social Sciences (COES\&RJ-JSS)

ISSN (E): 2305-9249 ISSN (P): 2305-9494

Publisher: Centre of Excellence for Scientific \& Research Journalism, COES\&RJ LLC

Online Publication Date: $1^{\text {st }}$ October 2017

Online Issue: Volume 6, Number 4, October 2017

DOI: $10.25255 /$ jss.2017.6.4.762.774

\title{
Management System Internal Quality Assurance Higher Education (Multi Case At Higher Education Universitas Gajah Mada \\ "UGM"Yogyakarta, State Islamic Institute of IAIN Tulungagung, Balitar Islamic University "UNISBA" Blitar) \\ Anang Dwi Putransu Aspranawa \\ Postgraduated Education Program Universitty State of Malang Indonesia \\ Bambang Budi Wiyono, Ali Imron, Muhamad Huda AY \\ Departement of Education Management State University of Malang Indonesia
}

\section{Abstract:}

Quality assurance is the process of establishing and fulfilling quality standards with consistent, systematic and sustainable management, to meet the needs of stakeholders. Universities are qualified if they are able to realize their vision through the implementation of their mission, and able to meet the needs of stakeholders. The research was conducted in 3 (three) universities including Gadjah Mada University Yogyakarta, Tulungagung State Islamic Institute and Balitar Blitar Islamic University. The purpose of this study is to describe in detail the internal quality assurance management system of Gajah Mada University Yogyakarta, Tulungagung State Islamic Institute and Univertas Islam Balitar Blitar, specific "Implementation of internal quality assurance of universities described through a cycle of internal quality assurance system management activities which includes Standard Setting, Standard Implementation, Standard Evaluation, Standard Control and Standard Enhancement.This type of research is qualitative with multi case study design and descriptive study method. Source data using person or respondent as informant. Data collection, with Interview / Interview technique, Observation, and Documentation. Data analysis using interactive model analysis of idea of Miles and Huberman consists of three activities, namely; data reduction, data presentation, and conclusion / verification.Conclusion The results of research at 3 (three) colleges of Gadjah Mada University Yogyakarta, Tulungagung State Islamic Institute and Balit Islam Univertas Balitar Islamic University of Balitar Blitar has run internal assurance of internal quality that is regulated integrally through the realization of Tri Darma Perguruan Tinggi. The implementation of the quality of education is run on an ongoing basis with the stipulation of quality standards of education refers to the Vision \& $\mathrm{n}$ Missions, and legislation of education regulation enforced nationally and internationally. Implementation of Quality Standard runs academic and non academic field. Evaluation of Education Quality Standards in the process of realization of Tri Darma Higher Education through monitoring with its activities Internal Quality Audit, Control of Quality Standards of education through self-evaluation activities, Improving the quality standard of education conducted on the basis of the results of internal audits and self-evaluation.

Keywords:

quality assurance, Quality standard, Higher education, college

Citation:

Aspranawa, Anang Dwi Putransu; Wiyono, Bambang Budi; Imron, Ali; Huda AY, Muhamad (2017); Management System Internal Quality Assurance Higher Education (Multi Case At Higher Education Universitas Gajah Mada "UGM"Yogyakarta, State Islamic Institute of IAIN Tulungagung, Balitar Islamic University "UNISBA" Blitar); Journal of Social Sciences (COES\&RJ-JSS), Vol.6,No.4,pp:762-774; DOI: 10.25255/jss.2017.6.4.762.774.

This work is licensed under a Creative Commons Attribution 4.0 International License. 


\section{Introduction}

Education in Higher Education is one form of science and technology cultivation to make human beings intellectual, intellectual and scientific by processing the shaping and cultivate keahlihan, skills demanded must be quality and quality. According to Goetsch and Davis (1994) define the quality or the quality of a dynamic condition associated with service products, human beings, processes and environments that meet or exceed expectations, According to Juran (1993) "Quality is a match to the product," which can be the basis for managing the quality of education to something of quality-quality itensitasnya to users / users, customers and stakeholders.

Implementation of universities is the management / management of education seeks to achieve the goals set. Unsuccessful university to achieve quality education due to lack of capable management of structured and standardized in the sense of oprasional management system and factors involved in it is still in imperfection, unpreparedness to meet the quality of education set. Also described in the dissertation on the quality of higher education in Hong Kong by Tsui, Cecelia. (2002: 3). It was found that: "the quality of education is a reaction to a number of related state changes". Earnest Joshua (2001) the emergence of quality improvement due to the lack of ability of graduates in entering the world of work ". Therefore, universities are expected to improve their capacity through strengthening the governance of quality assurance system that can be done with the improvement and continuous development in a system whose implementation is realized through the activity of management, stewardship or more precisely called applying internal quality assurance management system of higher education.

Quality assurance college is ideally to maintain the quality of education, the quality of universities to be good if the internal quality assurance system goes well. Similarly, colleges that make problems with the withdrawal of the license of the study program even disabled for beroprasional, because the result of one of them is not the internal quality assurance management system of colleges well. (DIKTI, 2003) "Universities are qualified if they are able to realize their vision through the implementation of their mission, and are able to meet the needs of stakeholders, in the form of social needs (needs, industrial needs), professional needs"

\section{Literature Review \\ Quality assurance}

Prior to the review of the theory of quality assurance it would be good to understand the meaning of "Quality" etymologically derived from the Latin "Qualis" which means "what kind of" in the sense of quality has a meaning that varies: according to standards, as expected, in accordance with the agreement ' And others. To ensure the meaning of quality to be more complete and ethical besides the above statement quoted some opinions of quality meanings.

According to (Jay Schlickman, 2003: 19); "Quality is something that is not absolute but more to what is acceptable from the customer side", According to (Payne, 2000: 272) "Internal quality is based on compliance with external specifications and quality based on perceived from customers" Goetsch and Davis (1994 ) Defines the quality or quality of a dynamic condition associated with a service product, human, process and environment that meets or exceeds expectations. ISO 9000: 2000 in Hoyle's book (2007: 10) Quality is the ability of a set of characteristics that the product has to meet the requirements . 
From the explanation and some opinions above that "Quality" is the result of a process in the form of goods and / or services in accordance with established standards. And aplikatipnya quality in education in college is the level of conformity between the implementation of higher education with Higher Education Standards set. The rest ensures that all characteristics and performance in accordance with the standards / expectations / requirements are called Quality Assurance, the following are cited several opinions According to Elliot (1993) Quality assurance is all the systematic plans and actions necessary to provide the trust used to satisfy the needs Certainly, according to (1993), quality assurance is an activity to provide evidence to build trust that quality can function effectively. Clarified Cartin (1999: 312) in his batteries as follows: "Quality Assurance is all planned and systematic activities imposed in the quality system that can be demonstrated to provide confidence that a product or service will fulfill requirements for quality".

Referring from several definitions can be understood that the meaning of quality assurance (quality assurance) there are 2 (two) point of view as which as mentioned in the guidebook of quality assurance university (2003) is "First; the meaning of general quality assurance is the process of determining and fulfilling quality standards with consistent, systematic and sustainable management, so that consumers, producers, and other interested parties gain satisfaction and trust in the products offered. Second; the meaning of special quality assurance in the environment of higher education is the process of planning, determining, controlling and developing quality standard of management of higher education consistently and continuously, so that internal stakeholders (students, lecturers and employees) and external (community, business world, professional association, ) from universities obtain satisfaction "(Directorate of Academic Higher Education, 2009)

\section{Quality Assurance System of Higher Education (SPM-PT)}

In the guidebook of quality assurance (2017) Explained in Article 52 of the Dikti Law "systemic activities to improve the quality of higher education on a planned and sustainable basis is called the Higher Education Quality Assurance System (SPM-PT)", the application is initiated by universities by implementing the Quality Assurance System Internal (SPMI) with its activities form a cycle abbreviated as PPEPP, stands for abbreviation and explanation as follows: (1) Determination. Standard of Higher Education, which is standard setting activity consisting of SN Dikti and Guidance of Quality System of Higher Education of Higher Education of Higher Education Standard stipulated by university; (2) Implementation. Standard of Higher Education, which is the fulfillment activity of standard consisting of SN Dikti and Dikti standard set by university; (3) Evaluation. the implementation of the Higher Education Standard, which is the comparative activity between the outcome of standard fulfillment activity with the standard consisting of SN Dikti and Dikti Standard set by the university; (4) Control. Implementationof the Higher Education Standard, which is the standard cause analysis activity consisting of SN Dikti and Dikti Standard set by universities that are not achieved for corrective action; (5) Enhancement.Standard of Higher Education, which is standard improvement activity consisting of national standard of higher education and higher education standard to be higher than standard consisting of national standard of higher education and predefined higher education standard. 
Structure of Quality Assurance System of Higher Education based on Permendikbud No. 50 Year 2014 is classified into 3 (three) arrangements: First, Internal Quality Assurance System (SPMI): that is systemic activity of quality assurance of higher education by each university autonomously or independently to control and improve the organization of higher education on a planned and sustainable basis; Second, External Quality Assurance System is an assessment activity through accreditation to determine the feasibility of study program and college ;, Third Database of Higher Education, which is data collection and information of higher education of all universities in Indonesia which is integrated nationally (Kemenristek Dikti Directorate of quality assurance 2017)

\section{Quality Management System of Higher Education}

Quality Assurance Management System is an action Embodiment assure the activities of quality and quality of implementation process and results. Quality Assurance Management System of education includes education input, education process, educational output and educational outcome. In the meaning of educational input expressed with the meaning of quality-quality when in the readiness for learning process activities, the process of education is expressed with the meaning of quality-quality when in the implementation of effective and efficient learning activities, as well as output of education and outcome expressed by the meaning of quality-quality when the results of graduates Of the provision of education may be admissible in the world of work and / or used for the fulfillment of interests. The following illustrates the quality management system of higher education in which there are elements and / or functions of supporting standards of higher education and applicative on the points of high quality education appear in the following figure:

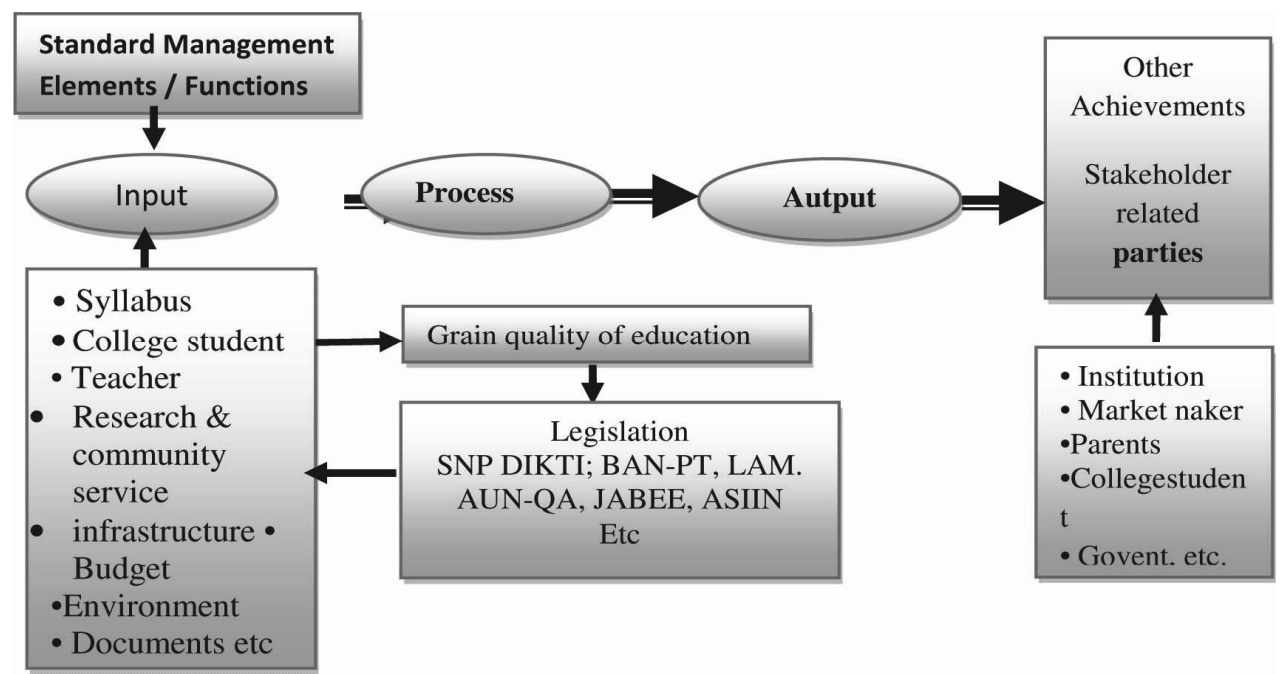

Picture: High Quality Management System of Education

Efforts to improve the quality of education can not be separated by the quality of education management. In quality management, all management functions undertaken by education management actors are directed to be able to provide satisfaction to their customers (customers), especially to customers / external stakeholders. In order to provide satisfaction to the customer, a certain guideline or standard is required as a criterion, and the educational services provided must conform to the established standards; all education 
management functions are directed to ensure that all educational services provided at least meet customer expectations and / or who are interested.

\section{Quality Control Management}

Management Quality control is a quality improvement activity to make it better, To maintain the quality of applied quality control and quality assurance. While quality assurance is a system designed to stipulate quality standards and meet the needs of stakeholders. Quality control management prioritizes satisfaction for users and stakeholders. The emphasis is on continuous improvement efforts.

To emphasize the statement cited several opinions from Barnawi and Arifin: 2017: 174 "Quality control in quality management is: A system of routine technical activities designed to measure and assess the quality of products or services provided to customers", ISO 9001 Management System Quality is to ensure that the final product of production can achieve customer satisfaction standards, errors in preparation and production can affect the outcome. Dr. J.M. Jurandan Dr. E.W. Deming 'to improve the quality and productivity of industry work / services mentioned there are 4 (four) basic principles of internal control: (1) The division of the right task; (2) Personnel Qualification; (3) Procedures, recording, and reporting of recorded transactions / documentation; (4) Consistent performance ', Further Barnawi and Arifin (2017: 175-176) in the following quality control process steps: (1) Setting the standard as the basis for control. (2) Measuring the activity by comparing the implementation and the results achieved in accordance with the standards of the established instruments. (Evaluation, correction and if any deviation needs corrective action) (3) Implementing internal benchmarking and always checking the implementation process, objectives, and implementation of the program in accordance with existing standards.

Quality control is needed especially in educational institutions, this is to ensure the quality of education itself so that the level of satisfaction from consumers or customers can be realized.

Efforts

\section{Research Objectives}

The purpose of this study describes in detail the management system of internal quality assurance three (3) colleges Gajah Mada University, State Islamic Institute Tulungagung and Univertas Islam Balitar Blitar, specific "Implementation of internal quality assurance colleges that are translated through a cycle Management activities internal quality assurance system which cover: a.Determination of Higher Standards, b.Implementation of Standard Education Standard, c.Evaluation of the implementation of the Higher Education Standard., d.Control Standards of Higher Education, e.Improved Standards of Higher Education

\section{Research Methods}

The research used qualitative approach with multi case design and descriptive study method. as in his opinion (Bogdan and Biklen, 1998: 4) the research of more than one subject requires a deep observation of the natural situation (Natuaralistic setting). The purpose of this study is to provide a comprehensive overview covering the characteristics, 
elemental values and factors associated with the Internal Quality Assurance System in 3 (three) Universities with different characteristics can be seen in the following table:

Table 1: Differences in the characteristics of the study setting

\begin{tabular}{|c|c|c|c|}
\hline \multirow[t]{2}{*}{ Aspect } & \multicolumn{3}{|c|}{ College } \\
\hline & UGM Yogyakarta & IAIN T Agung & UNISBA Blitar \\
\hline Manager & Government & Government & Foundation \\
\hline Thn Stand & 19 December 1949 & July 17,1968 & May 6, 2001 \\
\hline Campus location & $\begin{array}{l}\text { Jogjakara J1 Bulak well } \\
\text { Central Java }\end{array}$ & $\begin{array}{l}\text { J1 Mayor Sujadi } \\
\text { Tulungagung East Java }\end{array}$ & $\begin{array}{l}\text { J1 Mojopahit No } 4 \text { Blitar } \\
\text { Jatim }\end{array}$ \\
\hline Vision & $\begin{array}{l}\text { University of Gadjah } \\
\text { Mada as a pioneer of } \\
\text { world class universities } \\
\text { that excel and } \\
\text { innovative, serve the } \\
\text { interests of the nation } \\
\text { and humanitv is imhned }\end{array}$ & $\begin{array}{l}\text { The formation of } \\
\text { academic society based } \\
\text { on the principles of } \\
\text { science, berakhlaq }\end{array}$ & $\begin{array}{l}\text { Becoming a university of } \\
\text { international standard } \\
\text { through the excellence of } \\
\text { management, information } \\
\text { technology, and human } \\
\text { resources with the } \\
\text { strenothening of }\end{array}$ \\
\hline & $\begin{array}{l}\text { the nation's cultural } \\
\text { values based on } \\
\text { Pancasila. }\end{array}$ & & $\begin{array}{l}\text { entrepreneurial campus by } \\
\text { still upholding the value of } \\
\text { Islam and local wisdom }\end{array}$ \\
\hline $\begin{array}{l}\text { Implementation of } \\
\text { education }\end{array}$ & Tri Darma PT & Tri Darma PT & Tri Darma PT \\
\hline $\begin{array}{l}\text { OrganizationQuality } \\
\text { Guarantee }\end{array}$ & $\begin{array}{l}\text { Do not have religious } \\
\text { faculty }\end{array}$ & has a religious faculty & Tida has a religious faculty \\
\hline $\begin{array}{c}\text { Accreditation of } \\
\text { Higher Education } \\
\text { Institutions }\end{array}$ & $" A "$ & "B $"$ & "C" \\
\hline Culture & $\begin{array}{l}\text { Quality Assurance } \\
\text { Office }\end{array}$ & $\begin{array}{l}\text { Quality Assurance } \\
\text { Institution Led by } \\
\text { Chairman based on } \\
\text { Rector's Decree }\end{array}$ & $\begin{array}{l}\text { Quality Assurance Agency } \\
\text { Headed by Rector Decree }\end{array}$ \\
\hline
\end{tabular}

Selection Multi case design study due to setting or more than one case with different characteristics. Data source in this case Arikonto divide data into three groups (1) person, (2) place, (3) paper "this research more use data source in the form of person or respondent as informant. According to Moeleong, "To determine the informants in this study using techniques and specific purposes (purposive sampling), by snow ball (snow ball) is to keep the data needed to answer the questions. Data collection, conducted with Interview / Interview, Observation, and Documentation techniques, Description of this data collection along with a description of data recording.

Data analysis using interactive model analysis consisting of three activity flow, namely: data reduction, data presentation, and conclusion / verification. This Interactive Model Analysis is based on the ideas of Miles and Huberman (1992: 20)

\section{Data Exposure}

Implementation of internal quality assurance of universities Gajah Mada University of Yogyakarta, Tulungagung State Islamic Institute and the Islamic University of Balitar Blitar, as presented in the following table:

Determination standard of Higher Education 
The Implementation Of Curriculum Management ......

Table 2: Determination of Standards of Higher Education

\begin{tabular}{|c|c|c|c|c|c|}
\hline Description & No & $\begin{array}{l}\text { Higher } \\
\text { Education }\end{array}$ & $\begin{array}{l}\text { Vision Higher } \\
\text { Education }\end{array}$ & $\begin{array}{c}\text { Perpetrators } \\
\& \\
\text { parties } \\
\text { involved }\end{array}$ & $\begin{array}{l}\text { Standard Higher } \\
\text { Education / } \\
\text { Reference }\end{array}$ \\
\hline $\begin{array}{l}\text { - Quality assurance is } \\
\text { the process of } \\
\text { determining and } \\
\text { fulfilling the } \\
\text { standards of Higher } \\
\text { Education. } \\
\text { - - The quality } \\
\text { standards of Dikti } \\
\text { are used basic } \\
\text { guidelines of } \\
\text { education } \\
\text { implementation, } \\
\text { - - Standard of Higher } \\
\text { Education is } \\
\text { regulated / stipulated } \\
\text { by the Government } \\
\text { and there must be } \\
\text { established by PT. } \\
\text { - - Tinngi College has } \\
\text { the right to choose \& } \\
\text { formulate and apply } \\
\text { Standard Dikti with } \\
\text { - - Standard of Higher } \\
\text { Education is a basic } \\
\text { act in order to realize } \\
\text { the vision \& to fulfill } \\
\text { its mission } \\
\text { - - Determination of } \\
\text { Standard Dikti, is an }\end{array}$ & 2 & $\begin{array}{l}\text { Universitas } \\
\text { Gajah } \\
\text { Mada } \\
\text { Yoyakarta }\end{array}$ & $\begin{array}{l}\text { - Universitas Gadjah } \\
\text { Mada as a pioneer of } \\
\text { world class universities } \\
\text { that are superior and } \\
\text { innovative, serve the } \\
\text { interests of the nation } \\
\text { and humanity is } \\
\text { inspired by the nation's } \\
\text { cultural values based } \\
\text { on Pancasila. }\end{array}$ & $\begin{array}{l}\text { University; } \\
\text { - Rector and } \\
\text { His staff, } \\
\text { - The Senate } \\
\text { of PT } \\
\text { - Trustee } \\
\text { Faculty } \\
\text { - The Dean } \\
\text { and his staff, } \\
\text { - Senate Fak, } \\
\text { - Quality } \\
\text { Assurance } \\
\text { Office as a } \\
\text { facilitator }\end{array}$ & 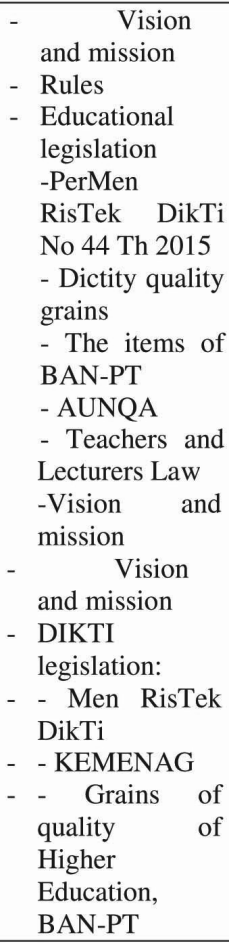 \\
\hline $\begin{array}{l}\text { activity } \\
\text { - Stipulation of } \\
\text { standards conducted } \\
\text { by PT by referring to } \\
\text { documents } \\
\text { Guidance of the } \\
\text { Higher Education } \\
\text { Quality Assurance } \\
\text { System (SPM- } \\
\text { PT) }\end{array}$ & 3 & $\begin{array}{l}\text { UNISBA } \\
\text { Blitar }\end{array}$ & $\begin{array}{l}\text { Becoming a university } \\
\text { of International } \\
\text { standard through the } \\
\text { excellence } \\
\text { management, } \\
\text { technology, and human } \\
\text { resources with the } \\
\text { strengthening of } \\
\text { entrepreneurial campus } \\
\text { based on information } \\
\text { technology, while } \\
\text { upholding the value of } \\
\text { Islam and local wisdom }\end{array}$ & $\begin{array}{l}\text { - Team formed } \\
\text { beranggotakn } \\
\text { structural } \\
\text { officials \& } \\
\text { lecturers }\end{array}$ & $\begin{array}{l}\text {-Vision and } \\
\text { mission } \\
\text { - DIKTI } \\
\text { legislation: } \\
\text { - Men RisTek } \\
\text { DikTi } \\
\text { - Foundation } \\
\text { Quality grain } \\
\text { of Higher } \\
\text { Education, } \\
\text { BAN-PT }\end{array}$ \\
\hline
\end{tabular}

\section{Implementation of Higher Education Standard}


Journal of Social Sciences (COES\&RJ-JSS), 6(4), pp. 762-774

Table 3: Implementation of Standards of Higher Education

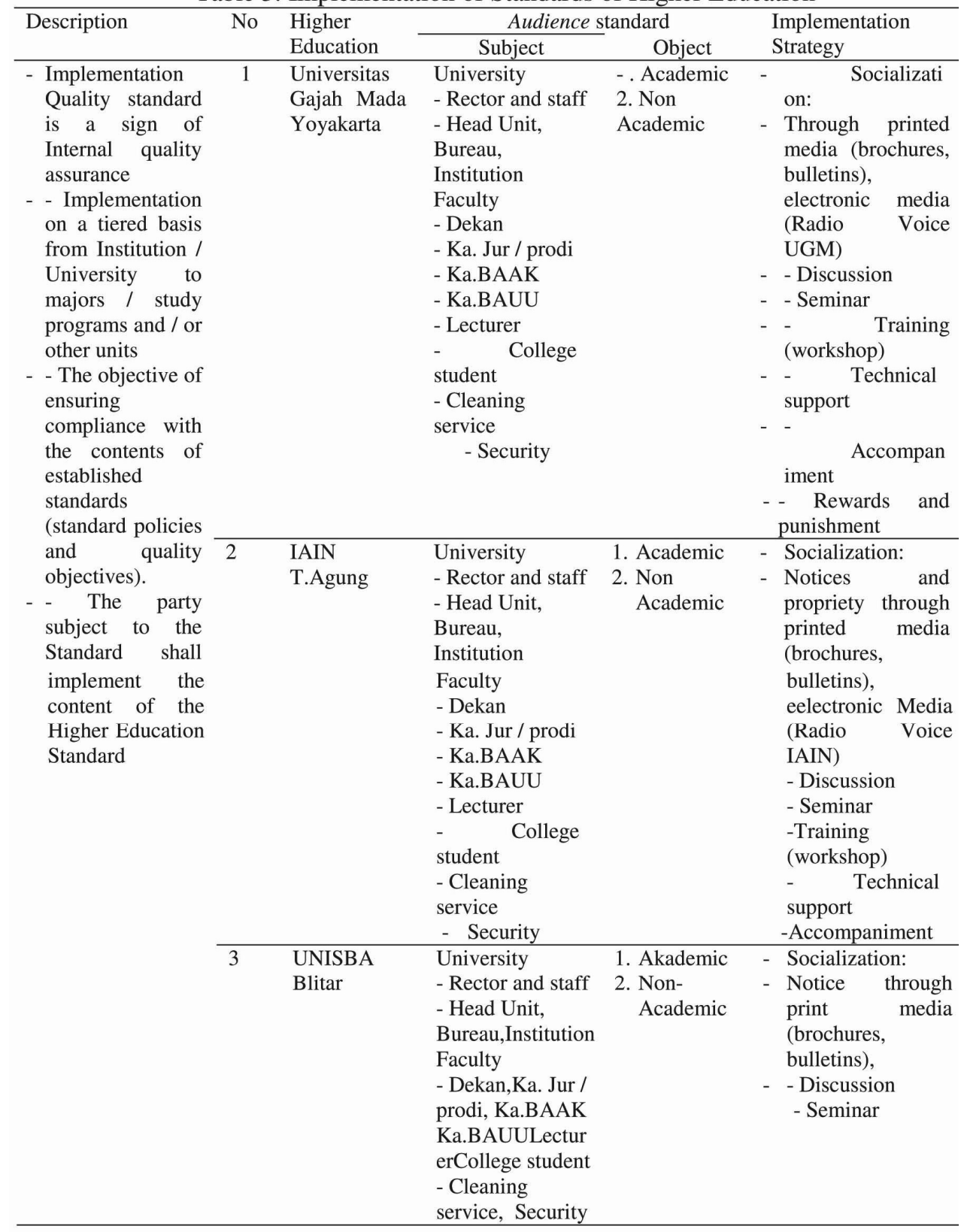

Evaluation of the implementation of the Higher Education Standards 
The Implementation Of Curriculum Management ......

Tabel 4: Evaluation of the implementation Standards

\begin{tabular}{|c|c|c|c|c|c|}
\hline Description & No & $\begin{array}{c}\text { Higher } \\
\text { Education }\end{array}$ & $\begin{array}{l}\text { Perpetrators } \\
\text { \&parties } \\
\text { involved }\end{array}$ & $\begin{array}{l}\text { Evaluation } \\
\text { Type }\end{array}$ & $\begin{array}{l}\text { Evaluation } \\
\text { Implementation }\end{array}$ \\
\hline \multirow{4}{*}{$\begin{array}{l}\text { Evaluation; Assessment } \\
\text { of standard content } \\
\text { implementation; } \\
\text { Processes, procedures, } \\
\text { mechanisms, and } \\
\text { outcomes or outputs } \\
\text { (summative evaluation). } \\
\text { - Evaluation of the } \\
\text { implementation of } \\
\text { quality standards Dikti } \\
\text { conducted collect and } \\
\text { process data } \\
\text { - The purpose of } \\
\text { evaluation to know the } \\
\text { weakness and / or } \\
\text { conformity to the } \\
\text { implementation of the } \\
\text { contents of quality } \\
\text { standards }\end{array}$} & 1 & $\begin{array}{l}\text { Universitas } \\
\text { Gajah Mada } \\
\text { Yoyakarta }\end{array}$ & 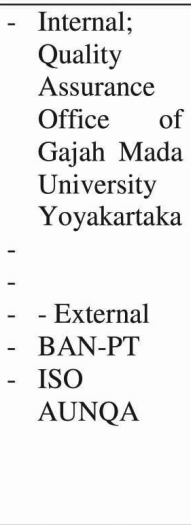 & $\begin{array}{l}\text { 1 Monevin- } \\
\text { Audit } \\
\text { Mutu } \\
\text { Internal } \\
\text { 1. Audit } \\
\text { Mutu } \\
\text { Eksternal }\end{array}$ & $\begin{array}{l}\text { Monitoring through } \\
\text { Audit with } \\
\text { oprasionalnya } \\
\text { circulating quisioner } \\
\text { to the manager / } \\
\text { pelaksaa, Lecturer } \\
\text { and Mhw } \\
\text { - Academic field } \\
\text { every academic year } \\
\text { minimum } 2 \text { times To } \\
\text { - Non-Akd field } \\
\text { periodically every th } \\
\text { Akd } \\
\text { - - Audit Quality } \\
\text { External } \\
\text { Accreditation }\end{array}$ \\
\hline & 2 & $\begin{array}{l}\text { IAIN } \\
\text { T.Agung }\end{array}$ & $\begin{array}{ll}\text { - } & \text { Internal; } \\
& \text { Quality } \\
& \text { Assurance } \\
& \text { IAIN } \\
\text { - } & \text { T. Agung } \\
\text { - } & \\
\text { - } & \\
\text { - } & \text { - External } \\
\text { - } & \text { BAN-PT }\end{array}$ & $\begin{array}{l}\text { 1. Monevin- } \\
\text { Audit } \\
\text { Mutu } \\
\text { Internal }\end{array}$ & $\begin{array}{l}\text { - Monitoring through } \\
\text { Audit with } \\
\text { oprasionalnya } \\
\text { circulating quisioner } \\
\text { to the manager / } \\
\text { pelaksaa, Lecturer } \\
\text { and Mhw } \\
\text { - Academic field } \\
\text { every academic year } \\
\text { minimum } 2 \text { times To } \\
\text { - Non-Akd field } \\
\text { periodically every th } \\
\text { Akd }\end{array}$ \\
\hline & & & $\begin{array}{l}\text { - Eksternal } \\
\text { BAN-PT }\end{array}$ & & $\begin{array}{l}\text { External Quality } \\
\text { Audit } \\
\text { - - Accreditation }\end{array}$ \\
\hline & 3 & $\begin{array}{l}\text { UNISBA } \\
\text { Blitar }\end{array}$ & $\begin{array}{l}\text { - Internal; } \\
\text { Quality } \\
\text { Assurance } \\
\text { UNISBA } \\
\text { Blitar }\end{array}$ & $\begin{array}{l}\text { 1. Monevin- } \\
\text { Audit } \\
\text { Mutu } \\
\text { Internal } \\
\\
2 \text { Audit } \\
\text { Mutu } \\
\text { Eksternal }\end{array}$ & $\begin{array}{l}\text { Monituring through } \\
\text { Audit with } \\
\text { oprasionalnya } \\
\text { circulating quisioner } \\
\text { to the manager / } \\
\text { pelaksaa, Lecturer } \\
\text { and Mhw } \\
\text { - Academic field } \\
\text { every academic year } \\
\text { minimum } 2 \text { times To } \\
\text { - Non-Akd field } \\
\text { periodically every th } \\
\text { Akd } \\
\text { External Quality } \\
\text { Audit } \\
\quad \text { Accreditati }\end{array}$ \\
\hline
\end{tabular}

\section{Control of Higher Education Standards}


Journal of Social Sciences (COES\&RJ-JSS), 6(4), pp. 762-774

Tabel 5: Pengedalian Standar Pendidikan Tinggi

\begin{tabular}{|c|c|c|c|c|c|}
\hline Description & No & $\begin{array}{l}\text { Higher } \\
\text { Education }\end{array}$ & Type of Control & $\begin{array}{l}\text { Perpetrators } \\
\text { \&the parties } \\
\text { involved }\end{array}$ & $\begin{array}{l}\text { Implementation of } \\
\text { Control }\end{array}$ \\
\hline \multirow{3}{*}{$\begin{array}{l}\text { - Control as a follow- } \\
\text { up to the results of } \\
\text { evaluation activities } \\
\text { (monitoring, quality } \\
\text { audit) } \\
\text { - Control } \\
\text { compliance with } \\
\text { specified standard } \\
\text { content purpose of } \\
\text { - The purion that the } \\
\text { ensuring the } \\
\text { contents of the true } \\
\text { standard can be met. } \\
\text { - Implementation of } \\
\text { corrective actions with } \\
\text { self-evaluation }\end{array}$} & 1 & $\begin{array}{l}\text { UGM } \\
\text { Yogyakarta }\end{array}$ & Self evaluation & $\begin{array}{l}\text { Coordinator } \\
\text { Department / } \\
\text { Prodi Quality } \\
\text { assurance } \\
\text { assisted ka } \\
\text { Prodi and } \\
\text { Lecturer }\end{array}$ & $\begin{array}{l}\text { Self-Evaluation in } \\
\text { each study } \\
\text { program at the } \\
\text { Faculty is done } \\
\text { twice every } \\
\text { academic year at } \\
\text { the end of the } \\
\text { semester }\end{array}$ \\
\hline & 2 & $\begin{array}{l}\text { IAIN } \\
\text { T ulungagung }\end{array}$ & Self evaluation & $\begin{array}{l}\text { Coordinator } \\
\text { Department / } \\
\text { Prodi Quality } \\
\text { assurance } \\
\text { assistedhead of } \\
\text { the study } \\
\text { program and } \\
\text { Lecturer }\end{array}$ & $\begin{array}{l}\text { Self-Evaluation in } \\
\text { each study } \\
\text { program at the } \\
\text { Faculty is done } \\
\text { twice every } \\
\text { academic year at } \\
\text { the end of the } \\
\text { semester }\end{array}$ \\
\hline & 3 & $\begin{array}{l}\text { UNISBA } \\
\text { Blitar }\end{array}$ & Self evaluation & $\begin{array}{l}\text { - Team } \\
\text { Committee, } \\
\text { Vice Rector } \\
\text { academic area } \\
\text { as facilitator }\end{array}$ & $\begin{array}{l}\text { Self Evaluation in } \\
\text { each study } \\
\text { program at } \\
\text { Faculty is done in } \\
\text { the process of } \\
\text { submission of } \\
\text { accreditation / } \\
\text { Reaccreditation }\end{array}$ \\
\hline
\end{tabular}

\section{Upgrading of Higher Education Standards}

Tabel 6: Peningkatan Standar Dikti

\begin{tabular}{|c|c|c|c|c|c|}
\hline Description & No & $\begin{array}{l}\text { Higher } \\
\text { Education }\end{array}$ & $\begin{array}{l}\text { Improved } \\
\text { Implementation }\end{array}$ & $\begin{array}{l}\text { Results / } \\
\text { Upgrades }\end{array}$ & $\begin{array}{l}\text { Actors \& parties } \\
\text { involved }\end{array}$ \\
\hline $\begin{array}{l}\text { Improvement of } \\
\text { Standards of Higher } \\
\text { Education is often } \\
\text { called kaizen or } \\
\text { continuous quality } \\
\text { improvement, } \\
\text { - Increased if } \\
\text { already running } \\
\text { SPMI } \\
\text { - The management } \\
\text { of SPMI includes } \\
\text { PPEPP activities } \\
\text { - Basis of } \\
\text { improvement } \\
\text { adjusts unfilled }\end{array}$ & 1 & $\begin{array}{l}\text { UGM } \\
\text { Yogyakarta }\end{array}$ & $\begin{array}{l}\text { Improvement of } \\
\text { academic } \\
\text { quality is done } \\
\text { through } \\
\text { Management } \\
\text { Review Meeting } \\
\text { (RTM) based on } \\
\text { findings of } \\
\text { Internal Quality } \\
\text { Monitoring \& } \\
\text { Audit Result, } \\
\text { Quality } \\
\text { Assurance } \\
\text { Office as } \\
\text { facilitator }\end{array}$ & $\begin{array}{l}\text { Academic Field } \\
\text { - Improvement } \\
\text { of quality } \\
\text { Lecturer } \\
\text { addition of } \\
\text { lecturer's } \\
\text { scientific work } \\
\text { either through } \\
\text { research tau } \\
\text { community } \\
\text { service, } 1 \text { th } \\
\text { academic } \\
\text { enhanced } \\
\text { menenjadi } 2 \\
\text { result of } \\
\text { scientific work. }\end{array}$ & $\begin{array}{l}\text { Formulator: } \\
\text { - LPPM, Vice } \\
\text { Rector for } \\
\text { Academic } \\
\text { Affairs, Vice } \\
\text { Dean for } \\
\text { Academic } \\
\text { Affairs. } \\
\text { - Decision: } \\
\text { Rector } \\
\text { - Pelaksna: } \\
\text { Lecturer } \\
\text { - Controller: } \\
\text { Quality } \\
\text { assurance office }\end{array}$ \\
\hline
\end{tabular}


The Implementation Of Curriculum Management ......

\begin{tabular}{|c|c|c|c|c|c|}
\hline \multirow[t]{4}{*}{$\begin{array}{l}\text { mission vision, } \\
\text { development, } \\
\text { progress of science } \\
\text { and technology, as } \\
\text { well as demand of } \\
\text { stakeholders } \\
\text { (steakholder) } \\
\text { - Itensity of } \\
\text { achievement results } \\
\text { against established } \\
\text { quality standards,) } \\
\text { can be done } \\
\text { continuous } \\
\text { approach } \\
\text { (continuous } \\
\text { approach) }\end{array}$} & & & $\begin{array}{l}\text { - Improved } \\
\text { partnership } \\
\text { cooperation } \\
\text { with university } \\
\text { overseas } \\
\text { universities in } \\
\text { France }\end{array}$ & $\begin{array}{l}\text { - The addition } \\
\text { of } \\
\text { international } \\
\text { class Prodi } \\
\text { with the } \\
\text { formulation of } \\
\text { international } \\
\text { standard } \\
\text { curriculum of } \\
\text { higher } \\
\text { education }\end{array}$ & $\begin{array}{l}\text { Formulator: } \\
\text { - Vice Rector for } \\
\text { Academic } \\
\text { Affairs, Dean, } \\
\text { Vice Dean of } \\
\text { Academic } \\
\text { Affairs. } \\
\text { - Decision: } \\
\text { Rector } \\
\text { - Pelaksna: } \\
\text { Lecturer } \\
\text { - Controller: } \\
\text { Quality } \\
\text { assurance office }\end{array}$ \\
\hline & 2 & $\begin{array}{l}\text { IAIN } \\
\text { T Agung }\end{array}$ & $\begin{array}{l}\text { Meeting the } \\
\text { findings of } \\
\text { Internal Quality } \\
\text { Assurance } \\
\text { Quality } \\
\text { Monitoring \& } \\
\text { Audit results as } \\
\text { a facilitator }\end{array}$ & $\begin{array}{l}\text { Academic } \\
\text { - New S1,S2, S3 } \\
\text { Non-Academic } \\
\text { - - Additional } \\
\text { facilities } \\
\text { Infrastructure } \\
\text { facilities }\end{array}$ & $\begin{array}{l}\text { Academic } \\
\text { Formulator: } \\
\text { - Vice Rector for } \\
\text { Academic } \\
\text { Affairs, Dean, } \\
\text { Vice Dean of } \\
\text { Academic } \\
\text { Affairs. } \\
\text {-Decision: } \\
\text { Rector } \\
\text { Executor: } \\
\text { Lecturer } \\
\text { Controller: } \\
\text { Quality } \\
\text { assurance } \\
\text { institution }\end{array}$ \\
\hline & 3 & $\begin{array}{l}\text { UNISBA } \\
\text { Blitar }\end{array}$ & $\begin{array}{l}\text { Proposal of } \\
\text { Annual Meeting } \\
\text { Evaluation of } \\
\text { High Perguan } \\
\text { Rector assisted } \\
\text { by Vice Rector } \\
\text { as Facilitator }\end{array}$ & $\begin{array}{l}\text { - Academic } \\
\text { Enhancement } \\
\text { Value / } \\
\text { Accreditation } \\
\text { status d each } \\
\text { study program } \\
\text { - Non Academic } \\
\text { Addition of } \\
\text { facilities for } \\
\text { college lecture }\end{array}$ & $\begin{array}{l}\text { Academic } \\
\text { Formulator: } \\
\text { - Vice Rector for } \\
\text { Academic } \\
\text { Affairs, and } \\
\text { General Affairs } \\
\text { - Dean, Vice } \\
\text { Dean for } \\
\text { Academic } \\
\text { Affairs. }\end{array}$ \\
\hline & & & & $\begin{array}{l}\text { facilities and } \\
\text { lecture rooms }\end{array}$ & $\begin{array}{l}\text { Decision: } \\
\text { Rector } \\
\text { - Executor: } \\
\text { Lecturer } \\
\text { - Controlle } \\
\text { Vice Rector for } \\
\text { Academic }\end{array}$ \\
\hline
\end{tabular}

\section{Conclusion}

Based on the study of internal quality assurance management system of higher education at 3 (three) universities covering Gajah Mada University Yogyakarta, Tulungagung State Islamic Institute of Religion and Balitar Blitar Islamic University, it can be concluded that 3 (three) universities have run internal assurance of quality is arranged integrally starting from education and teaching, up to research and devotion to society. the quality of education is run continuously (continuous improvement) in the sense of quality standard of education, stipulating quality standard of education, implementing quality standard of 
education, evaluating the implementation of quality standard of education, controlling the implementation of quality standard of education and improving quality standard of education executed by itself.

The differences that exist in 3 (three) universities include the University of Gajah Mada Yogyakarta, Tulungagung State Islamic Institute and the Islamic University of Balitar Blitar in the internal quality assurance management system as follows: (1) Determination of quality standard of higher education of Gadjah Mada University Yogyakarta, referring to Vision \& Mission, PerMen RisTek DikTi No 44 Th 2015, Dictity Quality Grain, Item BAN-PT. AUNQA. Tulungagung State Islamic Institute refers to Vision \& Mission, PerMen RisTek DikTi No 44 Th 2015 and Balitar Blitar Islamic University refers to Vision \& Mission, PerMen RisTek DikTi No 44 Th 2015. (2) Implementation of high quality education standard, Gajah Mada University Yogyakarta Implementation strategy using Socialization: through print media (brochure, bulletin), electronic media (Voice Radio UGM), Discussion, Seminar, Training of Technical Assistance Workshop. Assistance, Rewards and punishmen, Tulungagung Institute of Islamic Religion Implementation strategy using Socialization: through printed media (brochures, bulletins), electronic media (Radio Voice IAIN Tulungagung), Discussion, Seminar, Training (workshop), and Universitas Islam Balitar Blitar using Socialization through University and Faculty meetings. (3) Evaluation of quality standard of higher education to (3) three universities conduct monitoring through Internal Quality Audit and External Quality Audit with evaluation result: Gadjah Mada University yogyakarta sustainable development / improvement, Tulungagung State Islamic Institute of continuous development / improvement, Islamic University of Balitar Blitar correction and / improvement especially the vision vision of PT. (4) Control of quality standards of higher education to (3) three universities to control, but there are differences between the perpetrators and parties involved Gajah Mada University Yogyakarta team Coordinator Department / Prodi quality assurance and involving lecturer and lecturer, Tulungagung State Institute of Religious Affairs team Coordinator Majors / Prodi and involving study program and lecturer, Islamic University of Balitar Blitar formed Team Committee, Vice Rector academic area as facilitator. (5) Improvement of Dikt Standards The quality improvement of Gadjah Mada University Yogyakarta is done through Management Review Meeting (RTM) based on the findings of Internal Quality Monitoring \& Audit Result, Quality Assurance Office as facilitator, Tulungagung State Islamic Institute Meeting findings of Internal Quality Monitoring \& Audit Result Mutu as facilitator, Islamic University of Balitar Blitar Proposal of Annual Meeting Evaluation of High Perguan Rector assisted by Vice Rector as Facilitator.

\section{References}

Arikunto, Suharsimi. (2013). Prosedur Penelitian Suatu Pendekatan Praktik. Jakarta: Rineka Cipta.

Barnawi dan M. Arifin 2017. Sistem Penjaminan Mutu Pendidikan. Teori dan Praktik. Ar Ruzz Media. Yogyakarta.

Bogdan RC dan Biklen S.K, 1998. Qualitatif Research for Education; An Introduction To Theory and Method. Allyn and Bacon. Inc. Massachussets

Cecelia T, 2002. Quality in Higher Education: Policies and Practices; a Perspective Introduction and research Approach. Dissertation. Hongkong

Cartin, Thomas J. (1999). Principles and Practices of Organizational Performance. Excellence. Wisconsin: ASQ Quality Press. 
Damme, Van, Dirk. 2002.Trend and Models In International Quality Assuranceand accreditation in Higher education, In relation to trade in EducationServices.Washington D.C. : US Forum on Trade in Educational Services 23-24 May 2002.

Degeng I S, 1997, Strategi Pembelajaran, mengorganisasi isi dengan model Eraborasi, Malang: Ikatan ProfesiTeknologi Pendidikan Indonesia.

Ditjen Dikti. 2003, Pedoman Penjaminan Mutu Pendidikan Tinggi,Departemen Pendidikan Nasional, Direktorat Jenderal Pendidikan Tinggi

Direktorat Akademik Dirjen Dikti, 2009, Praktik Baik Dalam Penjaminan MutuPendidikan tinggi Buku XIII Manajemen Kelembagaan DepartemenPendidikan Nasional

Earnest, Joshua. 2001.Competency-Based Engineering Curriculum, AnInno vative Approach. Oslo: International Conference on EngineeringEducation. August 6-10 2001.

Elliot.(1993). "Management of Quality in Computing Systems Education: ISO

Goetsch, D.L \& Davis, S, 1994 Introduction to Total Quality, Quality, Productivity, Competitiveness, Englewood Cliffs, NJ, Prentice Hall International Inc

Hoyle, David., 2007.( ISO 9000:2000)Quality. ManagemantEssentials. Jordan Hill:

Elseiver Limited

Jackson, N. 1998 Understanding standard based qualitative assurance part II, nuts bolts of dearing policy work. Qualitative assurance in education $v 6$

Jay Schlickman 2003; GLP Quality Audit Manual, 3rd Edition.

Joseph M. Juran. dan Dr. E.W. Deming1989. Quality Control Handbook. New York. Mc. Grow Hill

Juran, Gryna. 1993. Quality Planning and Analysis, $3{ }^{\text {rd }}$ Edition. New York: Mc Graw Hill, Inc

Kementerian Riset, Teknologi, dan Pendidikan Tinggi, Dikrektorat Jenderal Pembelajaran dan Kemahasiswaan. 2016. Pedoman Sistem Penjaminan Mutu Pedidikan Tinggi. Direktorat Penjaminan mutu, Jakarta.

Miles, B. Mathew dan Michael Huberman. 1992. Analisis Data Kualitatif Buku Sumber Tentang Metode-metode Baru. Jakarta: UIP

Moleong, Lexy J. 2013. Metode Penelitian Kualitatif. Edisi Revisi.Bandung : PT. Remaja Rosdakarya Payne A, 2000 The Essence of service marketing, penerbit andi Yogyakarta 2017. Pedoman Sistem Penjaminan Mutu Pedidikan Tinggi, Kementerian Riset, Teknologi, dan Pendidikan Tinggi, Dikrektorat Jenderal Pembelajaran dan Kemahasiswaan, Direktorat Penjaminan Mutu, Jakarta.

Permendikbud No. 50 Tahun 2014, Struktur Sistem Penjaminan Mutu Pendidikan Tinggi (SPM-PT), (Pedoman Sistem Penjaminan Mutu Pedidikan Tinggi 2017, Dikrektorat Jenderal Pembelajaran dan Kemahasiswaan, Direktorat Penjaminan mutu, Jakarta

Peraturan Menteri Riset, Teknologi, dan Pendidikan Tinggi Republik Indonesia, No. 44 tahun 2015, tentang StandarNasional Pendidikan TInggi.

Pendidikan Tinggi. Undang-Undang Republik Indonesia No. 12 tahun 2012 tentang

Penjaminan mutu, Jakarta

Soemantri, B. Satryo. 2004. The Indonesian Higher Education 2003-2010.Jakarta : Directorate General Of Higher Education. 